\title{
Real-Time RT-PCR Analysis for Evaluating the Her2/neu Status in Breast Cancer
}

\author{
M. Cuadros ${ }^{a, c} \quad$ P. Talavera ${ }^{c} \quad$ F.J. López ${ }^{a} \quad$ I. García-Peréz ${ }^{b} \quad$ A. Blanco ${ }^{a}$ \\ A. Conchab, \\ ${ }^{a}$ Department of Computational Science and Artificial Intelligence, University of Granada, \\ ${ }^{b}$ Department of Pathology, and ${ }^{\mathrm{C} T i s s u e}$ and Tumor Bank, Department of Pathology, \\ Hospital Universitario Virgen de las Nieves, Granada, Spain
}

\section{Key Words}

Immunohistochemistry $\cdot$ In situ hybridization •

Fluorescence $\cdot$ Quantitative RT-PCR $\cdot$ mRNA quantification •

Breast cancer $\cdot \mathrm{c}$-erbB2 $\cdot$ Her2/neu

\begin{abstract}
Objective: The Her2/neu status is of great clinical value in breast tumor patients. Fluorescence in situ hybridization (FISH) and immunohistochemistry (IHC) techniques are the test of choice for many practicing pathologies. The main objective of this retrospective study was to investigate the relationship between Her2/neu breast cancer amplification and overexpression (DNA, mRNA and protein). Methods: To accomplish this goal, we evaluated Her2/neu mRNA expression by real-time quantitative RT-PCR, gene amplification by FISH and protein expression by IHC. Results: An excellent correlation between FISH and IHC Her2/neu results was observed, confirming that protein levels were directly related to DNA amplification. Polysomy 17 was frequently found in tumors showing Her2/neu overexpression. However, we did not find any statistically significant correlation among DNA, mRNA and protein levels, suggesting that Her2/neu could be post-transcriptionally regulated. Conclusions: There was a high agreement between Her2/neu gene amplification and protein overexpression but not mRNA expression levels. Nevertheless, IHC3+ and FISH-positive tumors indicated
\end{abstract}

higher expression levels of Her2/neu mRNA by RT-PCR than those observed in IHC and FISH-negative tumors. These findings question the relevance of quantitative RT-PCR in routine assessment of Her2/neu overexpression in human breast cancer in the clinical laboratory setting.

Copyright $\odot 2010$ S. Karger AG, Basel

\section{Introduction}

The human epidermal growth factor (ErbB2/Her2/ neu) is a proto-oncogene located on chromosome 17 (17q21) that encodes a transmembrane growth factor receptor with tyrosine kinase activity [1]. Her2/neu is overexpressed in $15-20 \%$ of invasive breast cancers [2-4], which is associated with aggressive biological behavior and resistance to certain chemotherapeutic agents [4]. In breast tumors, amplification of the Her2/neu gene and overexpression of protein are of great clinical value since it is an eligibility requirement for trastuzumab therapy [5]. In addition, when the disease progressed after prior treatment with an anthracycline, a taxane and trastuzumab, a selective inhibitor (lapatinib) of both epidermal growth factor receptor (ErbB1/EGFR/Her1) and Her2/ neu has demonstrated benefit in combination with capecitabine in patients with Her2-positive locally advanced and metastatic breast cancer [6]. Recently, it was

\section{KARGER}

Fax +4161306 1234

E-Mail karger@karger.ch

www.karger.com (c) 2010 S. Karger AG, Basel

1015-2008/10/0771-0038\$26.00/0

Accessible online at:

www.karger.com/pat
Marta Cuadros, $\mathrm{PhD}$

Department of Computational Science and Artificial Intelligence

University of Granada

c/Daniel Saucedo Aranda, s/n, ES-18071 Granada (Spain)

Tel. +34 958244 019, Fax +34958243 317, E-Mail cuadroslujan@yahoo.es 
described that patients with low expressing Her2/neu tumors exhibited better response with decreased breast cancer recurrence and no mortality following E75 vaccination [7].

Her2/neu activation can be studied at the levels of DNA, mRNA and protein, though 2 diagnostic techniques are the tests of choice for most pathologists and are often used together on paraffin-embedded block tissue sections processed in routine practice for assessing protein overexpression and gene amplification: immunohistochemistry (IHC) and fluorescence in situ hybridization (FISH). Comparative studies have shown high concordance rates between protein levels and amplification status in tumors scored as 0 or $1+$ (negative) and $3+$ (strongly positive) and variable results among cases scored as $2+$ (equivocal). The IHC2+ scoring controversy stems from the fact that these 2 tests evaluate different aspects of Her2/neu and their results can be influenced by tissue processing and fixation, interobserver variability and a scoring based on standardized cutoff level [8]. In these cases, FISH is universally considered the gold standard for confirming or excluding cases read as $2+$ immunohistochemically and identifying patients who are likely to respond to trastuzumab [9].

Our aim was to explore the potential of Her2/neu mRNA expression levels in breast tumors and to investigate its relation to IHC and FISH in order to determine the status of Her2/neu oncogene in DNA, RNA and protein levels. We compared the expression levels of mRNA Her2/neu with IHC scores, as well as with FISH results. Analyses of the Her2/neu status using IHC gave consistent results with those carried out using FISH, supporting the idea that levels of Her2/neu protein were associated with the gene amplification status. However, there was no statistically significant correlation among quantitative RT-PCR (qRT-PCR) and IHC, as well as among FISH results. These findings suggested that Her2/neu mRNA expression by qRT-PCR could not be an alternative method to IHC and FISH in the clinical laboratory setting, and they indicated that another Her2/neu activation mechanism should be considered.

\section{Material and Methods}

\section{Patients and Samples}

DNA, RNA and paraffin-embedded samples were retrospectively collected from 81 breast tumor patients (their characteristics are provided in table 1). All tumor tissue samples were collected from the Tissue and Tumor Bank of the Virgen de las Nieves Universitary Hospital after histological diagnosis between the years 2003 and 2007. Patients provided written acknowledgement and informed consent in accordance with institutional and national guidelines.

DNA and RNA were extracted from macrodissected frozen samples according to standard procedures using Trizol and TriReagent, respectively. The amount of tumoral cells was evaluated by microscopic evaluation of hematoxylin- and eosin-stained sections. Only samples of tumors with $\geq 80 \%$ tumoral cells were included in this study.

\section{Immunohistochemistry}

The immunohistochemical testing was performed at 1 of the 5 Spanish National HER2 Reference Laboratories, in which at least 800 tests are performed annually. Paraffin-embedded tissue sections were stained by the same technician with Hercep Test ${ }^{\mathrm{TM}}$ (Dako Diagnostic) in an automatic stainer (Autostainer plus ${ }^{\mathrm{TM}}$, Dako Diagnostic), and the degree of staining was scored by 2 blinded pathologists (A.C. and P.T.) according to the Hercep Test criteria and the American Society of Clinical Oncology and the College of American Pathologist HER2 testing guidelines (table 2).

\section{FISH Analysis}

FISH was performed on all paraffin-embedded tissues and cut into 4 - to 5 - $\mu \mathrm{m}$ sections using HER2 FISH pharmDx ${ }^{\mathrm{TM}}$ (Dako Diagnostic). FISH was carried out according to the method recommended by Dako Diagnostic. This kit contained specific DNA probes to the Her2/neu gene locus and to the centromeric region of chromosome 17 (CEP17). FISH testing results are a semiquantitative method based on the average ratio of Her2/neu signals to CEP17 signals in nonoverlapping interphase nuclei of the lesion. Specimens with a Her2/neu:CEP17 ratio of $\geq 2: 2$ were considered positive for gene amplification. FISH results were divided into 3 main categories: no amplification, low amplification and high amplification (table 2). The Her2/neu:CEP17 signals were visualized by a blinded pathologist (A.C.). This test allowed a simultaneous determination of chromosome 17 copies. Polysomy 17 was defined as the occurrence of $\geq 3$ copy numbers of centromeres for chromosome 17 per cell [10].

\section{qRT-PCR Analysis of Her $2 /$ neu}

We determined the level of expression of Her2/neu mRNA by real-time qRT-PCR. RNA was extracted from fresh frozen tissues using Trizol ${ }^{\mathrm{TM}}$ (Invitrogen) according to the manufacturer's instructions. We optimized a fluorescent staining with SYBR ${ }^{\mathrm{TM}}$ Green quantitative real-time RT-PCR assay for detection of the Her2/neu using SmartCycler (Cepheid Innovation). One microgram of RNA was used for reverse transcription with Improm II ${ }^{\mathrm{TM}}$ Reverse Transcription System (Promega) using oligo(dT) primers (Promega). PCR reactions contained $5 \mu \mathrm{lcDNA}, 8 \mu \mathrm{l}$ SYBR PCR Master Mix (Qiagen) and $1 \mu$ l of each primer $(5 \mu \mathrm{M})$. PCR conditions were $15 \mathrm{~s}$ at $95^{\circ} \mathrm{C}, 20 \mathrm{~s}$ at $55^{\circ} \mathrm{C}$ and $20 \mathrm{~s}$ at $72^{\circ} \mathrm{C}$ for 40 cycles. Her2/neu transcripts were detected using the following primers. HER/neu-F: 5'-CCAGGACCTGCTGAACTGGT-3'; Her2/neuR: 5'-TGTACGAGCCGCACATCC-3'; glyceraldehyde-3-phosphate dehydrogenase (GAPDH)-A: 5'-GAAGATGGTGATGGGATTTC-3', and GAPDH-AS: 5'-GAAGGTGAAGGTCGGAGTC$3^{\prime}$. Expression was quantified following the analysis of a concentration of cDNA (1/50). All samples were measured in triplicate. For each experimental sample, the amount of the Her2/neu 
Table 1. Histological subtypes and basic demographic characteristics of 81 breast cancers

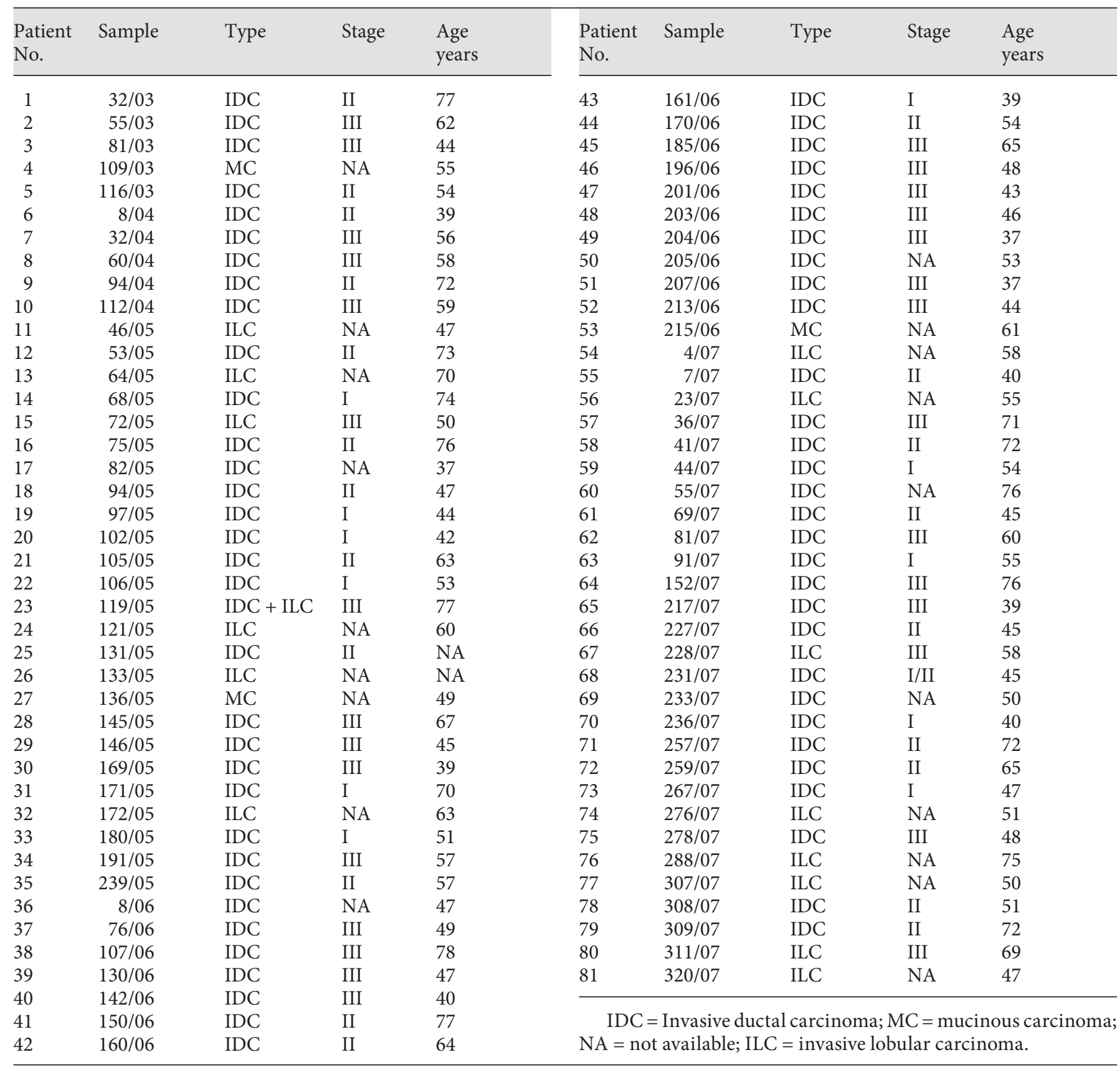

and endogenous reference (GAPDH) [11] was determined from the standard curves. These standard curves were composed of 6 points obtained from 6 -fold serial dilutions $(1,1 / 10,1 / 50,1 / 100$, $1 / 1,000$ and $1 / 10,000$ for Her2/neu and $1 / 10,1 / 100,1 / 500,1 / 1,000$, $1 / 10,000$ and $1 / 10,000$ for GAPDH) of cDNA from a breast tumor mRNA. We only considered experiments in which the linear relationships between the threshold cycle and the log of the amount of standard curve for Her2/neu and GAPDH were higher than 0.99 (correlation coefficient). Her2/neu was then divided by the amount of GAPDH to obtain a normalized value. GAPDH gene was used as an internal control for RNA quality RT and to correct the variations in the degree of RNA degradation.

\section{Statistical Methods}

Statistical significance of differences in transcript levels was assessed using Student's t test. Data analyses were carried out with the SPSS statistical software, version 15.0 (SPSS Inc., Chicago, Ill., USA).
Cuadros/Talavera/López/García-Peréz/ Blanco/Concha 
Table 2. CAP/ASCO scoring criteria of the IHC and FISH

\begin{tabular}{lll}
\hline Hercep Test (Dako Diagnostic) & & \\
\hline Cell membrane staining pattern & Score & HER2 status \\
\hline $\begin{array}{l}\text { No staining or membrane staining in } \\
<10 \% \text { of tumor cells }\end{array}$ & 0 & negative \\
\hline $\begin{array}{l}\text { A faint/barely perceptible membrane } \\
\text { staining in }>10 \% \text { of tumor cells }\end{array}$ & $1+$ & negative \\
\hline $\begin{array}{l}\text { A weak to moderate complete membrane } \\
\text { staining in }>10 \% \text { of tumor cells }\end{array}$ & $2+$ & $\begin{array}{l}\text { weakly } \\
\text { positive }\end{array}$ \\
\hline $\begin{array}{l}\text { A strong complete membrane staining in } \\
>10 \% \text { of tumor cells }\end{array}$ & $3+$ & $\begin{array}{l}\text { strongly } \\
\text { positive }\end{array}$ \\
\hline \begin{tabular}{l} 
HER2 FISH pharmDx kit (Dako Diagnostic) \\
\hline
\end{tabular} & & \\
\hline
\end{tabular}

1. Count 20 nuclei per tissue specimen, when possible from distinct tumor areas

2. Calculate the HER $2 / \mathrm{CEN}-17$ ratio by dividing the total number of red HER2 signals by the total number of green CEN-17 signals. Specimens with a HER2/CEN-17 ratio $\geq 2$ should be considered HER2 gene amplified

3. Results at or near the cutoff (1.8-2.2) should be interpreted with caution. If the ratio is borderline (1.8-2.2), count an additional 20 nuclei and recalculate the ratio for the 40 nuclei

CAP/ASCO $=$ College of American Pathologists/American Society of Clinical Oncology.

\section{Results}

Description of Breast Tumors in the Study Group

We successfully studied Her2/neu by IHC, FISH and qRT-PCR in 81 breast cancer patients whose average age at diagnosis was 55 years. Of the 81 breast tumors included in this study, 13 were Her2/neu positive (IHC3+), 48 were negative (24 IHC 0 and $24 \mathrm{IHC1}$ ) and 20 were equivocal (IHC2+). FISH analysis was successful in 79 tumoral samples, since 2 tumors, scored as $\mathrm{IHC1}+$ and IHC3+, were not available by FISH. Her2/neu was amplified in $24 / 79$ tumors (30\%). The real-time RT-PCR method was carried out in 80 tumoral samples. In 78 tumoral samples, parallel results were available from the 3 methods (IHC, FISH and qRT-PCR).

\section{Evaluation of FISH and IHC Results}

Considering $\mathrm{IHC}, \mathrm{IHC} 1+$ and $\mathrm{IHC} 3+$, the Her2/neu FISH results were concordant with Her2/neu IHC results in 57 of 59 (96\%) samples (table 3). There was an excellent interassay agreement (100\%) in the 0 and $3+$ IHC subgroups, indicating in tumors scored as 0 and $3+$ that copy number changes at the DNA level were related to protein expression. The discrepancies were found in 2 IHC1+ tumors, which lowly amplified the copy number of Her2/neu, suggesting false-negative results by IHC or biological imbalance between amplification and protein expression. In addition, 10 of the 20 (50\%) equivocal IHC2+ cases showed gene amplification; 8 had high amplification and 2 had low amplification. The IHC2+ cases accompanied by gene amplification could be biologically related to $\mathrm{IHC} 3+$. An increased chromosome 17 copy number was observed in 22 tumors $(22 / 79,28 \%)$ : 1 was IHC0/FISH-, 5 were IHC1+/FISH-, 6 were IHC2+/ FISH-, 5 were $\mathrm{IHC} 2+/ \mathrm{FISH}+$ and 5 were $\mathrm{IHC} 3+$ / FISH+.

\section{Her2/neu mRNA Expression Levels in Breast Tumors}

The analysis of Her2/neu mRNA expression levels was carried out successfully in 80 breast tumor samples. We found that breast tumors showed heterogeneous expression of the Her2/neu transcript. In order to investigate the relationship among DNA, mRNA and protein levels in breast tumors, we compared the results obtained by FISH, qRT-PCR and IHC.

We estimated the mRNA differences between FISHpositive $(\mathrm{n}=23)$ and FISH-negative tumors $(\mathrm{n}=55)$. Breast tumors showed heterogeneous expression of Her2/ neu mRNA in both subgroups. Nevertheless, we found that FISH-positive tumors showed higher expression levels of Her2/neu (around 2 fold) than FISH-negative breast tumors ( $\mathrm{p}=0.218$ ) (fig. 1 ). Most FISH-positive tumors clearly overexpressed Her2/neu mRNA, with expression values between 0.0002 and 0.5958 and a median of 0.0218 , indicating a probable relation between the DNA and RNA expression levels.

We also analyzed the mRNA and protein expression of Her2/neu in 80 tumoral samples. Based on the IHC findings, the cases were assigned to 4 groups: group A, IHC3+; group B, IHC2+; group C, IHC1+; group D, IHC0. Data were analyzed in relation to these groups. In some cases, Her2/neu expression levels in IHC3+ tumors were higher $(\mathrm{p}=0.082)$ than those observed in negative samples (ICH0 and $\mathrm{IHC1+}$ ), with a median difference in expression levels of 4 , and also, no IHC3+ tumors were among the 10 lowest expressions (fig. 1). These findings suggested that protein overexpression could arise from the Her2/neu transcriptional activation. 
Table 3. Summarizes the Her2/neu results obtained with the 81 breast tumors

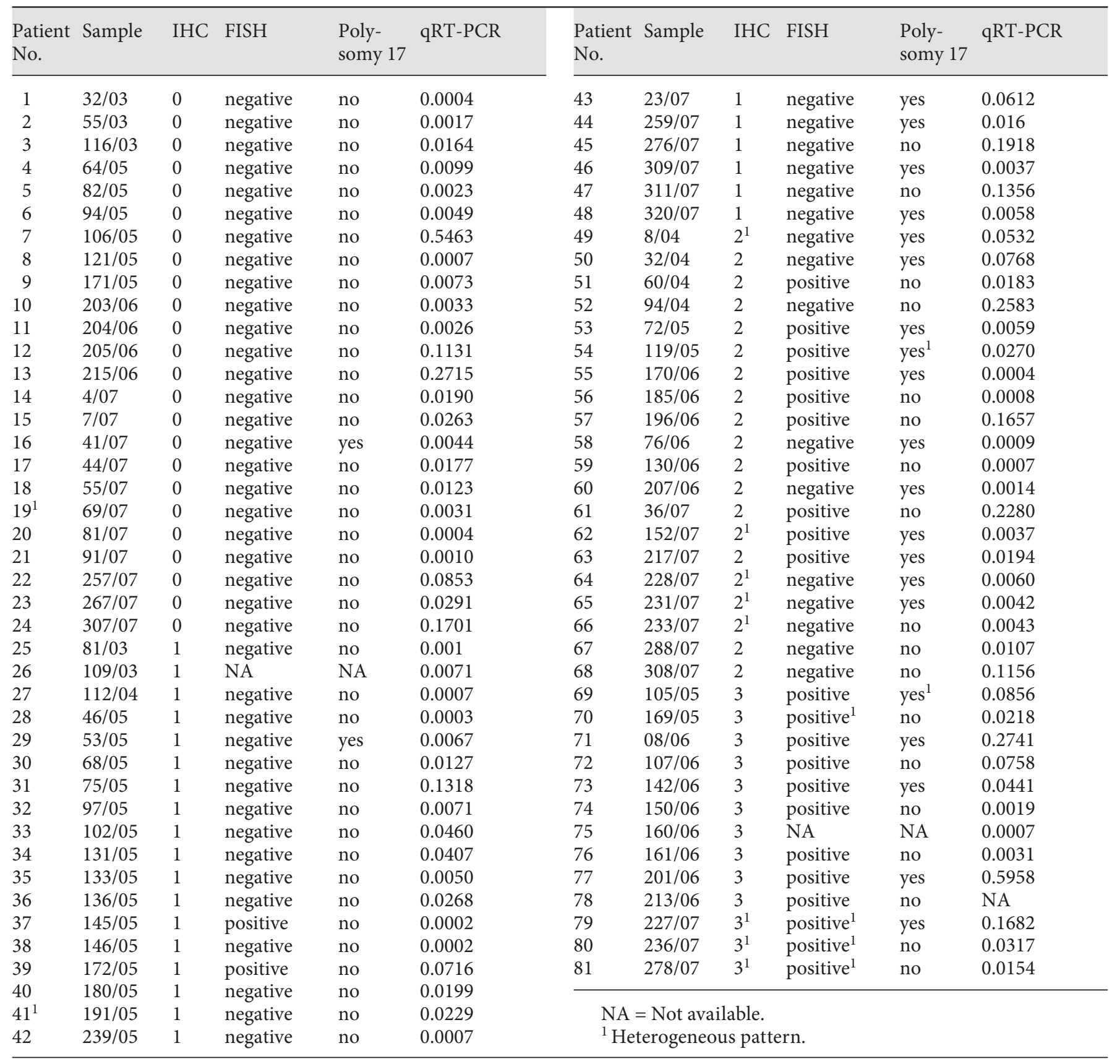

Her2/neu expression in IHC2+ tumors ranged from 0.0004 to 0.2583 with the same median as IHC negatives. However, 3 IHC2+ were found among the 10 highest Her2/neu expression cases; 2 of them showed high amplification by FISH, indicating that the status of the Her2/ neu in IHC2+ tumors remains an open question.

\section{Discussion}

Her2/neu activation is usually caused by amplification of the Her2/neu gene, resulting in an increased expression of human epidermal growth factor receptor 2 protein [12]. This increase in the number of Her2/neu 
Fig. 1. a Comparing the results of qRTPCR with IHC in cases scored as $0 / 1+$ and $3+$. b Expression levels of Her2/neu in FISH-positive and -negative breast tumors. The boxes show the 25 and $75 \%$ quartiles surrounding the median. The outlier values were only excluded from the graph, not from the data used to calculate medians and interquartile ranges.
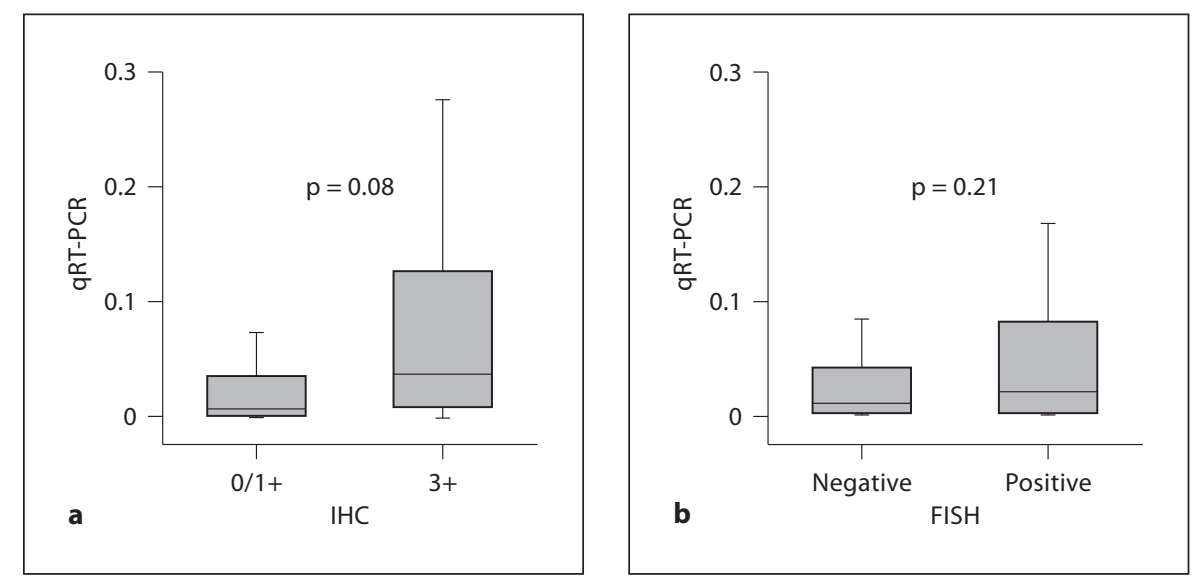

gene copies should be associated with overexpression of both mRNA and protein levels. Several studies have reported an almost complete concordance between Her2/ neu amplification detected by FISH and protein overexpression determined by IHC [13-15] although there was a relatively poor correlation between IHC and FISH in the IHC2+ category $[16,17]$. However, Her2/neu amplification can occur without protein overexpression, as well as Her2/neu overexpression can exhibit in the absence of Her2/neu amplification [18], suggesting that Her2/neu activation was induced by other mechanisms. In our experience as a HER2 testing Reference Laboratory of Spain (data not shown), 2,751 cases were studied by IHC and FISH from 2001 to 2007: HER2 IHC0/1+, IHC2+ and IHC3+ comprised 64, 20 and 16\%, respectively, while HER2 FISH-positive patients were $24 \%$ of the available population information. The level of agreement between local and reference laboratory HER2 IHC testing was $62 \%$ for $\mathrm{IHC} / 1+$ and $65 \%$ for $\mathrm{IHC} 3+$, and $91 \%$ for IHC0/1+ and 78\% for IHC3+, considering HER2 IHC and FISH results, respectively. Of the 530 tumors scored as IHC2+, $73 \%$ of them were classified as FISH negative while $27 \%$ showed Her2/neu amplification. In contrast to these results and current published data [13, $16,19]$, in this study, we found a high percentage of FISHpositive cases in the IHC2+ tumors and no case with Her2/neu amplification in the absence of protein expression, which could be due to inclusion criteria on sample selection.

Divergent results reported by FISH and IHC techniques might be related to methodological problems. Preanalytical and subjective variables, such as tissue handling and fixation, storage, criteria of interpretation and pathologist experience, as well as analytical vari- ables, such as antibody sensitivity and specificity, method of antigen retrieval and visualization system, can affect the accuracy of the results [20]. In addition, another possible cause of discrepancy between the results of FISH and IHC might be attributable to tumor biology. Her2/neu-positive tumors could have an excessive amount of the Her2/neu protein due to transcription activation.

In order to improve the knowledge of the biological events underlying Her2/neu-driven breast cancer and to evaluate the Her2/neu biological sequence at the DNA, mRNA and protein in breast tumors, we also carried out qRT-PCR analysis. It was limited by RNA conservation and degradation [21], dilution of tumoral cell component with stromal, inflammatory and normal epithelial cells [22] and the absence of standard protocols. As discussed by Perreard et al. [23] and Vinatzer et al. [24], the evaluation of Her2/neu mRNA expression did not show any statistically significant correlation with DNA amplification and protein expression. There was a clear overlap of expression levels of Her2/neu mRNA in the FISH and IHC subgroups, which could be explained on the heterogeneity of Her2/neu expression [25]. In spite of qRT-PCR representing an extremely sensitive and specific technique for determining transcript levels of Her2/neu [22], cases with Her2/neu amplification and low Her2/neu mRNA levels were observed according to Gjerdrum et al. [26] and Capizzi et al. [27]. Interestingly, most of the higher Her2/neu mRNA levels were observed in the IHC3+ and FISH-positive tumors, supporting the idea that there could be a direct relationship among DNA, RNA and protein levels. In these tumors, protein overexpression might arise from gene amplification and the consequent transcriptional activation that 
leads to a high number of Her2/neu proteins. Perhaps, the subgroup of IHC3+/FISH-positive/mRNA patients could be of high clinical interest $[22,28]$. We believe that breast tumors with high levels of Her2/neu mRNA might be considered as a category probably therapeutically and prognostically related to gene-amplified tumors, as well as IHC2+/FISH positives [29]. On the other hand, our observations in discordant tumors supported that other molecular mechanism, such as chromosome 17 polysomy [12], alternative splicing [30], specific promoter regulation [31], defective RNAs, mutations in Her2/neu and other related genes [32], as well as chromosomal translocations, might contribute to Her2/neu protein overexpression.

In summary, this study confirmed an excellent agreement between Her2/neu gene amplification and protein overexpression. Although the Her2/neu mRNA levels did not differ significantly among breast tumors classified on the basis of IHC and FISH criteria, we identified a subgroup of breast tumors in which there was a correlation among the DNA, mRNA and protein levels. Her2/neu transcript levels do not seem to be an alternative method to IHC and FISH, suggesting that another Her2/neu activation mechanism should be considered. Future studies are required to identify other Her2/neu activation mechanisms and to establish the best method for predicting the response of breast tumors to Her2/neu-targeted therapies.

\section{Acknowledgement}

This work has been carried out as part of the projects P08-TIC4299 and PO6-CTS-02200 of J.A., Sevilla and TIN2009-13489 of DGICT, Madrid.

\section{References}

1 Coussens L, Yang-Feng TL, Liao YC, Chen E, Gray A, McGrath J, Seeburg PH, Libermann TA, Schlessinger J, Francke U: Tyrosine kinase receptor with extensive homology to EGF receptor shares chromosomal location with neu oncogene. Science 1985;230:11321139.

-2 Olayioye MA, Graus-Porta D, Beerli RR, Rohrer J, Gay B, Hynes NE: ErbB-1 and ErbB-2 acquire distinct signaling properties dependent upon their dimerization partner. Mol Cell Biol 1998;18:5042-5051.

- 3 Schechter AL, Stern DF, Vaidyanathan L, Decker SJ, Drebin JA, Greene MI, Weinberg RA: The neu oncogene: an erb-B-related gene encoding a $185,000-\mathrm{Mr}$ tumour antigen. Nature 1984;312:513-516.

4 Slamon DJ, Clark GM, Wong SG, Levin WJ, Ullrich A, McGuire WL: Human breast cancer: correlation of relapse and survival with amplification of the HER-2/neu oncogene. Science 1987;235:177-182.

5 Bilous M, Dowsett M, Hanna W, Isola J, Lebeau A, Moreno A, Penault-Llorca F, Rüschoff J, Tomasic G, van de Vijver M: Current perspectives on HER2 testing: a review of national testing guidelines. Mod Pathol 2003; 16:173-182.

-6 Ulhoa-Cintra A, Greenberg L, Geyer CE: The emerging role of lapatinib in HER2-positive breast cancer. Curr Oncol Rep 2008; 10 : 10-17.

7 American Association for Cancer Research: Breast cancer prognosis: response to preventive HER2/neu peptide (E75) vaccine based on HER2/neu status. ScienceDaily. 2008. http://www.sciencedaily.com/releases/ 2008/04/080413163559.htm (accessed May $6,2008)$.
8 Ciampa A, Xu B, Ayata G, Baiyee D, Wallace $J$, Wertheimer M, Edmiston K, Khan A: HER-2 status in breast cancer: correlation of gene amplification by FISH with immunohistochemistry expression using advanced cellular imaging system. Appl Immunohistochem Mol Morphol 2006;14:132-137.

9 Bilous M, Ades C, Armes J, Bishop J, Brown R, Cooke B, Cummings M, Farshid G, Field A, Morey A, McKenzie P, Raymond W, Robbins P, Tan L: Predicting the HER2 status of breast cancer from basic histopathology data: an analysis of 1500 breast cancers as part of the HER2000 International Study. Breast 2003;12:92-98.

10 Salido M, Tusquets I, Corominas JM, Suarez M, Espinet B, Corzo C, Bellet M, Fabregat X, Serrano S, Solé F: Polysomy of chromosome 17 in breast cancer tumors showing an overexpression of ERBB2: a study of 175 cases using fluorescence in situ hybridization and immunohistochemistry. Breast Cancer Res 2005;7:R267-R273.

11 Vanden Bempt I, Vanhentenrijk V, Drijkoningen M, Wlodarska I, Vandenberghe P, De Wolf-Peeters C: Real-time reverse transcription-PCR and fluorescence in-situ hybridization are complementary to understand the mechanisms involved in HER-2/neu overexpression in human breast carcinomas. Histopathology 2005;46:431-441.

- 12 Hofmann M, Stoss O, Gaiser T, Kneitz H, Heinmöller P, Gutjahr T, Kaufmann M, Henkel T, Rüschoff J: Central HER2 IHC and FISH analysis in a trastuzumab (Herceptin) phase II monotherapy study: assessment of test sensitivity and impact of chromosome 17 polysomy. J Clin Pathol 2008;61: 89-94.
13 Kitano Y, Umemura S, Ohbayashi H, Takenaga $\mathrm{M}$, Osamura $\mathrm{RY}$ : Assessment of a new anti-HER2 monoclonal antibody, SV261gamma: a best concordance with HER2 FISH. Appl Immunohistochem Mol Morphol 2007;15:389-393.

- 14 Sidoni A, Ferri I, Cavaliere A, Bellezza G, Scheibel M, Bucciarelli E: Detection of HER2/neu (c-erbB-2) overexpression and amplification in breast carcinomas with ambiguous immunohistochemical results. A further contribution to defining the role of fluorescent in situ hybridization. Anticancer Res 2006;26:2333-2337.

15 Xu R, Perle MA, Inghirami G, Chan W, Delgado Y, Feiner H: Amplification of Her-2/ neu gene in Her-2/neu-overexpressing and -nonexpressing breast carcinomas and their synchronous benign, premalignant, and metastatic lesions detected by FISH in archival material. Mod Pathol 2002;15:116124.

16 Dybdal N, Leiberman G, Anderson S, McCune B, Bajamonde A, Cohen RL, Mass RD, Sanders C, Press MF: Determination of HER2 gene amplification by fluorescence in situ hybridization and concordance with the clinical trials immunohistochemical assay in women with metastatic breast cancer evaluated for treatment with trastuzumab. Breast Cancer Res Treat 2005;93:3-11.

17 Tsuda H, Akiyama F, Terasaki H, Hasegawa T, Kurosumi M, Shimadzu M, Yamamori S, Sakamoto G: Detection of HER-2/neu (c-erb B-2) DNA amplification in primary breast carcinoma. Interobserver reproducibility and correlation with immunohistochemical HER-2 overexpression. Cancer 2001;92: 2965-2974. 
18 Stark A, Hulka BS, Joens S, Novotny D, Thor AD, Wold LE, Schell MJ, Melton LJ 3rd, Liu ET, Conway K: HER-2/neu amplification in benign breast disease and the risk of subsequent breast cancer. J Clin Oncol 2000;18: 267-274.

-19 Yaziji H, Goldstein LC, Barry TS, Werling R, Hwang H, Ellis GK, Gralow JR, Livingston $\mathrm{RB}$, Gown AM: HER-2 testing in breast cancer using parallel tissue-based methods. JAMA 2004;291:1972-1977.

20 Cuadros M, Villegas R: Systematic review of HER2 breast cancer testing. Appl Immunohistochem Mol Morphol 2009;17:1-7.

-21 Stanta G, Mucelli SP, Petrera F, Bonin S, Bussolati G: A novel fixative improves opportunities of nucleic acids and proteomic analysis in human archive's tissues. Diagn Mol Pathol 2006;15:115-123.

-22 Barberis M, Pellegrini C, Cannone M, Arizzi C, Coggi G, Bosari S: Quantitative PCR and HER2 testing in breast cancer: a technical and cost-effectiveness analysis. Am J Clin Pathol 2008;129:563-570.

23 Perreard L, Fan C, Quackenbush JF, Mullins M, Gauthier NP, Nelson E, Mone M, Hansen H, Buys SS, Rasmussen K, Orrico AR, Dreher D, Walters R, Parker J, Hu Z, He X, Palazzo JP, Olopade OI, Szabo A, Perou CM, Bernard PS: Classification and risk stratification of invasive breast carcinomas using a real-time quantitative RT-PCR assay. Breast Cancer Res 2006;8:R23.
24 Vinatzer U, Dampier B, Streubel B, Pacher M, Seewald MJ, Stratowa C, Kaserer K, Schreiber M: Expression of HER2 and the coamplified genes GRB7 and MLN64 in human breast cancer: quantitative real-time reverse transcription-PCR as a diagnostic alternative to immunohistochemistry and fluorescence in situ hybridization. Clin Cancer Res 2005;11:8348-8357.

25 Kostopoulou E, Vageli D, Kaisaridou D, Nakou M, Netsika M, Vladica N, Daponte A, Koukoulis G: Comparative evaluation of non-informative HER-2 immunoreactions (2+) in breast carcinomas with FISH, CISH and QRT-PCR. Breast 2007; 16:615-624.

26 Gjerdrum LM, Sorensen BS, Kjeldsen E, Sorensen FB, Nexo E, Hamilton-Dutoit S: Realtime quantitative PCR of microdissected paraffin-embedded breast carcinoma: an alternative method for HER-2/neu analysis. J Mol Diagn 2004;6:42-51.

27 Capizzi E, Gruppioni E, Grigioni AD, Gabusi E, Grassigli A, Grigioni WF, Fiorentino M: Real time RT-PCR approach for the evaluation of ERBB2 overexpression in breast cancer archival samples: a comparative study with FISH, SISH, and immunohistochemistry. Diagn Mol Pathol 2008;17:220-226.
28 Bergqvist J, Ohd JF, Smeds J, Klaar S, Isola J, Nordgren $\mathrm{H}$, Elmberger GP, Hellborg $\mathrm{H}$, Bjohle J, Borg AL, Skoog L, Bergh J: Quantitative real-time PCR analysis and microarray-based RNA expression of HER2 in relation to outcome. Ann Oncol 2007; 18: 845-850.

29 Bartlett JM, Malln E, Cooke T: Molecular diagnostics for determination of HER2 status in breast cancer. Curr Diagn Pathol 2003;9: 48-55.

30 Kraus MH, Popescu NC, Amsbaugh SC, King CR: Overexpression of the EGF receptor-related proto-oncogene erbB-2 in human mammary tumor cell lines by different molecular mechanisms. EMBO J 1987;6:605610.

31 Miller SJ, Xing X, Xi L, Hung MC: Identification of a specific DNA region required for enhanced transcription of HER2/neu in the MDA-MB453 breast cancer cell line. DNA Cell Biol 1996;15:749-757.

32 Bremm A, Walch A, Fuchs M, Mages J, Duyster J, Keller G, Hermannstädter C, Becker KF, Rauser S, Langer R, von Weyhern $\mathrm{CH}$, Höfler H, Luber B: Enhanced activation of epidermal growth factor receptor caused by tumor-derived E-cadherin mutations. Cancer Res 2008;68:707-714. 